\title{
Корекційна остеотомія бічної кісточки гомілки при їі хибно консолідованих переломах
}

\author{
Т. М. Омельченко ${ }^{1}$, О. А. Бур'янов ${ }^{1}$, А. П. Лябах ${ }^{2}$, О. А. Турчин ${ }^{2}$ \\ ${ }^{1}$ Національний медичний університет імені О. О. Богомольця, м. Київ, \\ ${ }^{2}$ Інститут травматології та ортопедії НАМН України, м. Київ
}

\section{The corrective osteotomy of the shin lateral small bone in its falsely consolidated fractures}

\author{
T. M. Omelchenko', O. A. Burianov ${ }^{1}$, A. P. Lyabakh ${ }^{2}$, O. A. Turchin ${ }^{2}$ \\ ${ }^{1}$ Bogomolets National Medical University, Kyiv, \\ ${ }^{2}$ Institute of Traumatology and Orthopedics, Kyiv
}

\section{Реферат}

Мета. Проаналізувати результати застосування модифікованої методики корекційної остеотомії бічної кісточки гомілки при ії хибно консолідованих переломах без виражених деструктивно-дистрофічних змін травмованого гомілковостопного суглоба.

Матеріали і методи. Дослідження проведено щодо 37 пацієнтів, 3 них чоловіків - 16, жінок - 21, середній вік яких становив $(38 \pm 7)$ років. 3 моменту травми минуло від 6 до 15 міс, у середньому $-(7,8 \pm 1,9)$ міс. Під час рентгенологічного обстеження у пацієнтів виявлено післятравматичний остеоартроз гомілковостопного суглоба I-II стадії за Келгреном - Лоуренсом.

Корекційна остеотомія включала поперечну остеотомію бічної кісточки гомілки на рівні суглобової щілини гомілковостопного суглоба, що уможливило виконати трьохплощинну корекцію положення кісточки та відновити співвідношення в гомілковостопному суглобі.

Функціональні результати оцінювали за шкалою AOFAS (American Orthopaedic Foot and Ankle Society Score) для гомілковостопного суглоба та заднього відділу стопи до та після хірургічного лікування. Ступінь прогресування остеоартрозу визначали за результатами рентгенографії в навантаженні згідно з класифікацією Келгрена - Лоуренса. Середній термін спостереження з аналізом результатів становив $(1,9 \pm 0,6)$ року.

Результати. Оцінка функціональних результатів за шкалою AOFAS у межах терміну спостереження зросла $3(58,7 \pm 2,4)$ до $(86,2 \pm 1,8)$ бала. Під час ренттенологічного обстеження у всіх пацієнтів спостерігали відновлення осі гомілковостопного суглоба, але у 8 (21\%) пацієнтів виявили III стадію остеоартрозу, що свідчило про його прогресування.

Висновки. Модифікована методика корекційної остеотомії бічної кісточки гомілки при ії хибно консолідованих переломах дає змогу відновити конгруентність та біомеханічну вісь подкодженого суглоба, значно покращити його функціональну здатність та уповільнити прогресування післятравматичного остеоартрозу.

Ключові слова: бічна кісточка; корекційна остеотомія; післятравматичний остеоартроз; гомілковостопний суглоб; наслідки перелому кісточок гомілки.

\section{Abstract}

Objective. To analyze the results of application of modified procedure in the correction osteotomy of the shin lateral small bone in a falsely consolidated its fractures without significant destructive-dystrophic changes in tramatized ankle joint.

Materials and methods. The investigation was conducted in 37 patients, 16 - men and 21 - women, with average age (38 \pm 7) yrs. From the trauma moment $6-15$ mo passed, ( $7.8 \pm 1.9)$ mo at average. During roentgenological examination in patients with posttraumatic osteoarthrosis of ankle joint the Stages I-II in accordance to Kellgren and Lawrence were established. Correctional osteotomy have included a transverse osteotomy of lateral small bone of the shin on the level of the joint fissure, what made possible to perform a three-dimensional correction of the bone localization and to restore the interrelationship in ankle joint.

Functional results were estimated in accordance to the AOFAS (American Orthopaedic Foot and Ankle Society Score) scale for ankle joint and posterior part of foot before and after surgical treatment. The progression degree of osteoarthrosis were determined in accordance to result of roentgenography with loading in accordance to classification of Kellgren-Lawrence. Average term of observation with the results analysis have constituted $(1.9 \pm 0.6)$ yrs.

Results. Estimation of functional results in accordance to the AOFAS scale in borders of the follow-up term have increased from $(58.7 \pm 2.4)$ to $(86.2 \pm 1.8)$ points. During roentgenological examination in all the patients a restoration of the ankle joint axis was observed, but in 8 (21\%) patients the osteoporosis Stage III was revealed, what have witnessed its progress.

Conclusion. Modified procedure of the correction osteotomy of the shin lateral small bone in a its falsely consolidated fractures gives possibility to restore a congruence and biomechanical axis of the joint injured, to improve significantly its functional capacity and to slow down a progress of posttraumatic osteoarthrosis.

Keywords: lateral small bone; the correction osteotomy; posttraumatic osteoarthrosis; ankle joint; outcomes of fracture of smal bones of the shin.

Переломи кісточок гомілки за частотою виникнення займають друге місце після переломів променевої кістки в „типовому місці” та становлять 20 - 28\% від загального числа всіх переломів кісток скелета, 35 - 60\% - внутрішньосуглобових переломів нижніх кінцівок та 38 - 80\% переломів кісток гомілки [1 - 8]. Як і раніше, незадовіль- 
ні результати лікування даних пошкоджень констатують у $37 \%$ хворих [1, 2, 4 - 6]. Серед незадовільних результатів лікування головним є ранній та швидкий розвиток післятравматичного остеоартрозу гомілковостопного суглоба (ГСС), що призводить до первинної інвалідизації 8,8 - 46\% пацієнтів [1, 2, 5, 6]. Численними дослідженнями доведено, що малогомілкова кістка - це головний стабілізатор ГСС і від ії положення повністю залежать надп'ятково - великогомілкові взаємовідношення [1, 3, 4, 8, 9]. На підставі даних біомеханічних досліджень доведено, що зміщення по довжині та зовнішня ротація малогомілкової кістки у разі переломів кісточок із зовнішнім підзвихом стопи призводять до сублюксації надп'яткової кістки навіть тоді, коли дельтоподібна зв'язка залишається інтактною. Якщо переломи кісточок супроводжуються зміщенням надп'яткової кістки на 1 мм, це призводить до зменшення площі опорної поверхні на 42\% та двократного збільшення питомого тиску на суглобовий хрящ, а у разі зміщення надп'яткової кістки на 3 мм площа контакту у великогомілково-надп'ятковому зчленуванні зменшується більше ніж на 60\%.

Отже, позитивний результат лікування наслідків переломів кісточок гомілки можливо отримати тільки у разі усунення ротаційного зміщення та відновлення довжини малогомілкової кістки/бічної кісточки, що забезпечує відновлення біомеханічної осі та конгруентності ГСС. Якщо уламки бічної кісточки консолідовані в хибному положенні, їх роз'єднання з метою репозиції вкрай утруднене, а хірургічна процедура вельми травматична та непрогнозована через наявність порушень кровопостачання, локального остеопорозу, прогресуючих дегенеративно-дистрофічних змін суглобового хряща та кісток ГСС.

Мета дослідження: клініко-рентгенологічна оцінка результатів корекційної остеотомії бічної кісточки за модифікованою методикою у пацієнтів з хибною консолідацією переломів кісточок гомілки.

\section{Матеріали і методи дослідження}

Проаналізовано результати лікування 37 пацієнтів у відділенні патології стопи та складного протезування Інституту травматології та ортопедії НАМН України з 2008 по 2016 р. Чоловіків було 16, жінок - 21. Середній вік пацієнтів становив (38 \pm 7$)$ років. 3 моменту травми минуло від 6 до 15 міс, у середньому - $(7,8 \pm 1,9)$ міс. Під час рентгенологічного обстеження у пацієнтів констатували післятравматичний остеоартроз ГСС I-II стадії за класифікацією Келгрена - Лоуренса.

Функціональні результати оцінювали за шкалою AOFAS для гомілковостопного суглоба та заднього відділу стопи до виконання корекційної остеотомії, через 12 та 22 міс після хірургічного лікування. Ступінь прогресування остеоартрозу визначали за результатами рентгенографії в навантаженні згідно з класифікацією Келгрена - Лоуренса. Термін спостереження з аналізом результатів становив у середньому $(1,9 \pm 0,6)$ року.

Згідно з модифікованою нами методикою на першому етапі операції здійснювали ревізію медіальної зони ГСС з видаленням рубцево-змінених залишків капсульнозв'язкового апарату, які виповнювали розширений вну- трішньосуглобовий простір під присередньою кісточкою гомілки. Далі з латерального доступу до ГСС виконували поперечну остеотомію бічної кісточки на рівні горизонтальної суглобової щілини, залишаючи інтактним капсульно-зв'язковий апарат латеральної зони ГСС і не відшаровуючи окістя бічної кісточки. Остеотомовану бічну кісточку зводили, деротували, медіалізували та зміщували до переду, що давало змогу усунути дисконгруентність у ГСС. Простір, що утворювався після зведення та зміщення кісточки, заповнювали кістковим кортикально-спонгіозним аутотрансплантантом. У подальшому виконували металоостеосинтез пластиною, що давало змогу стабільно фіксувати трансплантант та кісточку в досягнутому положенні. Останнім етапом відновлювали дельтоподібну зв'язку та капсулу медіальної зони ГСС. Шкіру ушивали пошарово. Упродовж перших 4 тиж застосовували імобілізацію у гіпсовій пов'язці «чобіток», а впродовж наступних 4 тиж - функціональний ортез з дозованим навантаженням на оперовану кінцівку. Упродовж перших 4 тиж з метою оптимізації консолідації та перебудови кісткового аутотрансплантанта триразово вводили аутоплазму, збагачену тромбоцитами.

\section{Результати}

Застосовуючи модифіковану методику корекційної остеотомії з приводу хибно консолідованого перелому бічної кісточки гомілки, ми підвищили функціональну активність пацієнтів та досягли добрих функціональних результатів уже через 12 міс - оцінка за шкалою AOFAS становила $(78,4 \pm 2,3)$ бала, а через 22 міс зафіксовано подальший приріст функції, оцінений за шкалою AOFAS у $(86,2$ $\pm 1,8)$ бала (p < 0,01), тоді як середній рівень функціональної активності до лікування був оцінений у $(58,7 \pm 2,4)$ бала $(\mathrm{p}<0,01)$, що відповідало нижній межі діапазону оцінки задовільного функціонального результату за шкалою AOFAS для ГСС та заднього відділу стопи.

Під час рентгенологічного обстеження через 12 міс після операції констатували наявність кісткового зрощення з перебудовою кісткового аутотрансплантанта у всіх пацієнтів. Рентгенологічна оцінка конгруентності оперованого ГСС та вираженості післятравматичного остеоартрозу за класифікацією Келгрена - Лоуренса показала, що після виконання корекційної остеотомії у всіх пацієнтів було досягнуто відновлення анатомічних співвідношень у ГСС, але у 8 (21\%) з 37 пацієнтів через 22 міс зафіксовано III стадію остеоартрозу, що свідчило про його прогресування та позначилося на функціональному результаті.

\section{Обговорення}

Виконуючи корекційну остеотомію бічної кісточки, здебільшого застосовують косу остеотомію по лінії хибно консолідованого перелому або надкісточкову остеотомію в нижній третині малогомілкової кістки за типом замка або з поперечною площиною перерізу [2, 6, 8]. У разі виконання надкісточкової остеотомії створюють передумови лише для зведення вкороченої кісточки. Коса остеотомія по лінії зрощення дає можливість як усунути вкорочення, так і медіалізувати кісточку. Однак через наявність рубцевих змін у пошкодженій латеральній зоні, де- 
формації зламаної кісточки, післятравматичних змін, що виникають в зоні дистального міжгомілкового синдесмозу, відновлення анатомії та конгруентності ГСС з усуненням усіх компонентів деформації у фронтальній, горизонтальній та сагітальній площинах неможливо, а хірургічна процедура складна, травматична і важко контрольована. Виконання корекційної остеотомії за модифікованою нами методикою дає можливість контрольовано змінювати положення бічної кісточки в трьох площинах. Невиконання втручання в зоні перелому, а також збереження окістя та латеральної групи зв'язок ГСС забезпечують зменшення порушення кровопостачання та оптимізацію процесу відновлення функції ГСС. Важливим фактором для збереження структури та функції травмованого ГСС у разі хибно консолідованих переломів бічної кісточки є час, що минув з моменту травми, а також інтенсивність та тривалість навантаження при вкороченій, ротованій та зміщеній назад бічній кісточці, що супроводжується вираженим перевантаженням латеральної зони суглоба з незворотним руйнуванням суглобового хряща та швидким прогресуванням післятравматичного остеоартрозу. У 8 (21\%) пацієнтів, у яких з моменту травми до виконання корекції минуло понад 12 міс, незважаючи на відновлення конгруентності ГСС після виконаної корекційної остеотомії, через 22 міс спостерігали прогресування дегенеративно-дистрофічного процесу через незворотні зміни в суглобовому хрящі.

\section{Висновки}

У пацієнтів з хибно консолідованими переломами бічної кісточки гомілки за умови незначних або помірно виражених післятравматичних дегенеративно-дистрофічних змін у травмованому суглобі (остеоартроз I-II стадії за Келгреном - Лоуренсом) модифікована методика корекційної остеотомії бічної кісточки гомілки забезпечуе відновлення конгруентності та біомеханічної осі суглоба, значне покращення його функціональної здатності та уповільнення прогресування післятравматичного остеоартрозу.

\section{References}

1. Matte D, Swartman B, Grützner PA, et al. Trauma Berufskrankh. 2017;19 (Suppl 2):144. doi:10.1007/s10039-017-0273-7.

2. Roukis TS. Corrective ankle osteotomies. Clin Podiatry Med Surg. 2004 Jul;21(3):353-70. doi:10.1016/ j.cpm.2004.03.007.

3. Denise M. Mandi. Ankle Fractures. Clinics in Podiatric Medicine and Surgery. 2012;29(2):155-86. doi:10.1016/j.cpm.2012.01.002.

4. John Harris, Lawrence Fallat. Effects of isolated Weber B fibular fractures on the tibiotalar contact area. The Journal of Foot and Ankle Surgery, 2004;43(1): 3-9. doi:10.1053/j.jfas.2003.11.008.

5. Visser HJ, Malik K, Djali RA. Fibular-Lengthening Osteotomy to Correct a Malunited Ankle Fracture Using Fresh-Frozen Femoral Head Allograft. J Am Podiatr Med Assoc. 2017 Jul;107(4):318-323. doi: $10.7547 / 15-207$

6. Curtis MJ, Michelson JD, Urquhart MW, Byank RP, Jinnah RH. Tibiotalar contact and fibular malunion in ankle fractures. A cadaver study. Acta Orthopaedica Scandinavica, 1992;63(3):326-9, doi: 10.3109/17453679209154793.

7. Stroh DA, DeFontes K, Paez A, Parks B, \& Guyton GP. Distal fibular malrotation and lateral ankle contact characteristics. Foot Ankle Surg. 2017 Sep 20. pii: S1268-7731(17)31287-0. doi: 10.1016/j.fas.2017.09.001.

8. Kwon JY, Cronin P, Velasco B, Chiodo C. Evaluation and Significance of Mortise Instability in Supination External Rotation Fibula Fractures: A Review Article. Foot Ankle Int. 2018 Jul;39(7):865-873. doi: 10.1177/1071100718768509. 